\title{
Evaluation of tourism investment climate in Egypt after the twenty- fifth of January revolution 2011
}

\author{
Bassam Nour Hassan \\ tourism studies department, \\ faculty of tourism and Hotels, \\ Minia University
}

\author{
Prof. Hala Hilaly \\ tourism studies department, \\ faculty of tourism and Hotels, \\ Alexandria University
}

\begin{abstract}
Ph.D. M. Anter
Assistant professor in tourism studies department, faculty of tourism and Hotels, Minia University
\end{abstract}

\begin{abstract}
:
No doubt, the twenty-fifth of January revolution 2011 and its consequences have negatively affected the total investment especially in the tourism sector in Egypt. Moreover, there are a range of obstacles preventing the increase of tourism investment in Egypt, especially the foreign investment.

In line with this concern, the study aims at assessing the tourism investment climate in Egypt after the twenty-fifth of January revolution 2011 and its impact on the flow of foreign investments to Egypt. Consequently this work seeks to identify the impediments to tourism investment in Egypt and how to overcome them, moreover, measure the impact of the revolution of January 2011 on the volume of tourism investments in Egypt to determine the necessary efforts to increase the volume of tourism investments in Egypt; both, foreign and national.

To achieve the aim of the study, the researcher distributed 127 questionnaires on expert specialists in tourism and investment sector and received 97 questionnaires. After the collection of the questionnaire lists, the researcher has analyzed all data using the statistical package for social science analysis system SPSS version (18) and the $t$ results reveal that:

Media and social media helped in increasing the negative impact of $25^{\text {th }}$ January revolution on the tourism investment in Egypt, the risk for the tourism investor depends totally on security factor, Investment in the human resources is the most important type of investment to increase the income from tourism, in addition; tourism investment incentives provided by the government are not sufficient to restore the tourism investment flow.
\end{abstract}

Keywords: Tourism investment, Finance, $25^{\text {th }}$ January revolution 2011. 


\section{Introduction:}

Investment is one of the main pillars of economic development as well as it represents one of the most important tools for development in any country. Where it works to encourage and attract investment that helps the development of cities, cultivation and service activity, whether these investments are in public or private sectors (Iraqi et al, 2004). The state role to attract investments depends on many procedures including the investment policy of the country, the investment opportunity, the trade policy and the investment barriers. Governments play a fundamental role in setting up a lot of strategies which influence investors and implement policies to encourage the investment.

The tourism investment is important; particularly, to the national economy as it provides services to locals and foreigners. Furthermore, it provides jobs and reduces the unemployment rate (Meng, 2012). It also increases the state's capital financial sources, and improves the infrastructure, hotels, businesses and various tourist facilities which respectively lead to increase tourists flow to Egypt, increase revenues from tourism and tourism investment, and thus increasing the national income and average per capita and thus improving the standard of living. The efforts towards achieving the appropriate tourism investment flows face a group of obstacles, but the twenty-fifth of January revolution 2011 and its consequences are the main factors that have negatively affected the total investment especially in the tourism sector in Egypt, because of political instability and lack of security. Where the investment flow in tourism in the financial year (2010-2011) reached 5739 million ... While the financial year following the revolution (2011-2012) the tourism investment flow in Egypt reached 5.570 million, recording change rate about $-2.9 \%$. In the financial year (2012-2013) the investment flow in tourism rise to reach about 6630 million e.g., achieving positive change rate about $19.03 \%$. In (2013-2014) the investment flow volume dropped to 3.432 million, recording a negative change rate approximately by 48.2\% (Ministry of Finance - monthly financial report (2011:2014).

The study aims at assessing tourism investment climate in Egypt after the twenty-fifth of January revolution and its impact on the flow of foreign investments to Egypt. Consequently, this work seeks to achieve the following objectives:

Objective 1: Identifying obstacles to tourism investment in Egypt and how to overcome them.

Objective 2: Measuring the impact of political events experienced by Egypt after the revolution of January 2011 on the volume of tourism investments in Egypt. 
Objective 3: Determining the necessary efforts to increase the volume of tourism investments; both, foreign and national in Egypt.

Objective 4: Identifying the investment types which greatly affect tourism development.

Objective 5: clarifying the role of government and society in the field of attraction tourism investments.

\section{Investment and finance}

It is important to discuss the investment, its definitions, its types, the investment decision making process, the motivations for investment and the investment analysis. Moreover, it is also important to represent the definition of finance, the financial system and types of finance.

\subsection{Investment}

The investment in language means the "gain", the gain means the growth and increase, and moreover, "invest" means development, increase and growth in the final image will be of cash, financial, commercial and in the form of real estate (Meziany, 2009, 55).

Economically, Tianen $(2013,7)$ defined the Investment as "spending to capital and financial assets that are made by private or public organizations or governments in the expectation of getting future returns". In other words, Myles (2003, 6) mentioned that "investment is the sacrifice of current consumption in order to obtain increased consumption at a later date".

In addition, investment climate reflects the overall economic, legal, political and social conditions that contain the environment where the investment is made, and the components of this environment are complex (Arab Investment Guarantee Corporation, 1993, 19).

There are two main types of investment:

( Domestic investment

The type of investment that occurs in the community within the borders of the state (Sameh, 2012, 16).

2 Foreign investment

Is one of the most important forms of foreign funds received by the state due to insufficient domestic savings to finance investments (Huda, 2008). The foreign investment is divided into two types:

- Foreign direct investment FDI.

- Foreign indirect investment.

Both investors and host country have motives to achieve their goals, but there are determinants of FDI which are represented in: (Huda, 2008)

$\square$ Market size and growth rate (Center of Private International Projects, 2004). 
$\square$ Economic Stability (Abd-Elaziz, 2005).

$\checkmark$ Human resource development and supporting endogenous capacity.

$\square$ Providing suitable infrastructure (Menour and Nazir, 2000).

$\square$ Political stability

$\square$ Regulatory and legislative framework for investment (Hasab-Alla, 2005).

$\square$ Provides the fabric of local institutions successful

$\checkmark$ The degree of economic openness to the outside world.

Investment decision making is a step in the investment process which may involve a significant risk for the investor (Niskanen and Niskanen, 2007). There are several phases for investment decision making process. Investment process is always related to Investment Company's identity and to its planning culture. Researchers have found similarities in investment projects and have made findings in their investment processes. These processes have some phases that can be linked to various investment projects and companies. Myles (2003), Tianen (2013) mentioned the steps of the process as follow: determine objectives, choose value, conduct security analysis, portfolio construction, evaluation, and revision Portfolio.

Investment analysis studies financial securities for the purpose of successful investing. Investopedia site (2016) showed that Investment analysis is a broad term that encompasses many different aspects of investing. It can include analyzing past returns to make predictions about future returns, selecting the type of investment vehicle that is best for an investor's needs or evaluating securities such as stocks and bonds for valuation and investor specificity.

Investment income and risk: A return is the ultimate objective for any investor. But a relationship between return and risk is a key concept in finance. As finance and investments areas are built upon a common set of financial principles, the main characteristics of any investment are investment return and risk. However to compare various alternatives of investments the precise quantitative measures for both of these characteristics are needed (Strong and Robert, 1993).

\subsection{Finance}

Financing is an integral part of the investment process because it determines the ability of the investor to implement the project in addition; it helps the investor to manage his money. Therefore, it is defined as "the Science of studying the management of funds' and the management of fund as the system that includes the circulation of money, granting of 
credit, making of investments, and the provision of banking facilities" (Paramasivan and Subramanian, 2010, 1).

The financial system is a set of arrangements, conventionally embracing the lending and borrowing of funds by non-financial economic units and intermediation of this function by financial intermediaries in order to facilitate the transfer of funds, to create additional money when required, and to create market in debt and equity instruments (and their derivatives) so that the price and allocation of funds are determined efficiently (Vernimmen et al, 2005, 268). On the other hand, Vernimmen et al. (2005) viewed that the job of a financial system is to efficiently create financial liquidity for those investment projects that promise the highest profitability and that maximizes collective utility.

However, unlike other types of markets, a financial system does more than just achieving equilibrium between supply and demand. A financial system allows investors to convert current revenues into future consumption. It also provides current resources for borrowers, at the cost of reduced future spending.

More specifically, the study mentioned three dentitions of efficiency:

- Informational efficiency which refers to the ability of a market to fully and rapidly reflect new relevant information.

- Allocative efficiency which implies that markets channel resources to their most productive uses.

- Operational efficiency which concerns the property of markets to function with mini-mall operating costs.(Vernimmen et al, 2005)

There are several types of finance, Phillips and Faulkner (2005) indicated that the types of finance can be broken down into three broad categories: Public finance, Private finance and Public\&private finance.

\section{The impact of $25^{\text {th }}$ January revolution 2011 on the tourism investment}

This section will discuss the tourism investment, its definition, trends affecting tourism investment and its economic importance. Also, it will review the impact of $25^{\text {th }}$ January revolution 2011 on tourism, labor working in tourism, investment and tourism investment as well as its impact on some important economic sectors.

\subsection{Tourism investment}

Tourism is a fast-growing industry that involves many economic and social sectors, making it an excellent development vector. Not surprisingly, surveys have also shown that tourism is a high-priority 
industry for Investment Promotion Agencies (IPAs) throughout the world (Endo, 2006).

The process of the country to attract investments depends on many procedures including the investment policy of the country, the investment opportunity, the trade policy and the investment barriers. Governments play a fundamental role in setting up a lot of strategies which influence investors and implementing policies to encourage tourism investment. (Kikeri, et al. 2006)

Tourism investments are targeted to tourism industry, and such investments underlie and support tourism development. Tourism investments are important to tourism companies and to tourism destinations. By investing into tourism companies, their future productive vitality is stronger. Tourism investments affect the tourism destinations; as it supports the overall capacity to satisfy tourism demand. Generally tourism investments provide needed funds to develop tourism projects. Therefore, it affects tourism facilities, destinations and services enticing more tourists and bringing growth (Dwyer et al., 2010).

Tourism investment process describes how investment projects are being carried out in companies and organizations. Investment processes are always connected to companies' culture and planning practices. Researchers have found similarities in different companies' investment planning (Niskanen \& Niskanen, 2007). Furthermore, Niskanen \& Niskanen (2007) presents a six phase investment model which are; recognition phase, search phase, information retrieval phase, selection phase, funding phase and investment project implementation and monitoring phase.

FDI in tourism occurs when an investor based in one country (the home country) acquires an asset in another country (the host country) with the intent to manage that asset. The management dimension is what distinguishes FDI from portfolio investment in foreign stocks, bonds and other financial instruments. In such cases, the investor is typically referred to as the "parent firm" and the asset as the "affiliate" or "subsidiary".

There are some trends affecting tourism investment; will be shown in the following: (Ontario, 2009, 4:6)

1- Increasingly sophisticated travelers.

2- Out bound travelers from emerging country.

3- New tourism destination/competition for both investor and investment.

4- Globalization and growth in FDI.

5- Events used as a destinations draw.

6- Arts and culture used as a destination draw. 
7- Recreational real estate shared ownership products.

8- Sustainable tourism and greening the industry.

9- New products and experienced.

10- Weak tourism performance/increase investor risk.

Investment in tourist activity according to the analysis of the importance and impact analysis results in some important economic and social impacts as follow: (Wagdi, 2009)

1. The flow of foreign capital.

2. Tourism investment and its role in the achievement of urban cultural development.

3. The transfer of technological techniques.

4. Tourism investment and business opportunities.

5. Create and develop relations between the economic and service sectors and the tourism sector.

6. Tourism investment and the balance of payments.

\subsection{The impact of $25^{\text {th }}$ January 2011}

The economic challenges facing Egypt have been exacerbated after the 25th of January revolution mainly because of the deteriorating political and security conditions which have interrupted the functioning of the economy. Yet, this is not to say that revolution has caused these challenges. In fact, the challenges that the Egyptian economy has been facing have deep roots in its socio-political-economic context, which this point aims to explain. The revolution and its aftermath have brought to the forefront challenges which have always been mitigated by short-term solutions that never dealt seriously with their roots. Moreover, the revolution had brought additional problems associated with the macroeconomic imbalances. As a result, the challenges became more complex especially in light of the need to balance the social and economic aspects (Ghoneim, 2014).

\section{Challenges Facing the Egyptian Economy after 25 January revolution 2011:}

Despite the deeply rooted economic problems, the former regime in power up to the $25^{\text {th }}$ January 2011 was able to keep the macroeconomic balances under control. Over the period 2004-2010 the Egyptian economy was just doing perfect, with change rate exceeding $7 \%$ in some years, the budget deficit was in the range of $8-10 \%$ and was heavily controlled, the balance of payments had been turned into a surplus, and foreign exchange reserves where increasing. Moreover, foreign direct investment (FDI) has reached unprecedented levels (13 billion US\$). In fact, Egypt was 
appraised by international organizations for its remarkable good economic performance, which according to their standards has been improving over time. For example, Egypt was considered as the (top reformer) in 2006-2007 by Doing Business Report (2008), and improving in 5 of the 10 areas assessed by the report. Yet, performance was not reflected in improvements in the socio economic indicators, where the level of poverty remained high and income distribution did not improve. In other words, the governing regime before the $25^{\text {th }}$ of January revolution focused mainly on the economic aspects while leaving the social aspect relatively untouched (World Bank, 2008).

The events of the revolution 2011 and its consequences were the direct cause of increased poverty rate and the decline in some strategic economic activities in the Egyptian economy, such as:

1) The transformative industries sectors: as it achieved a negative change rate by $-3.8 \%$ during the financial year 2010/2011 sector (Ministry of Planning, 2012-2013).

2) The Suez Canal: It achieved a change rate about $12.7 \%$ during the financial year 2010/2011, but this rate dropped during the financial year 2011/2012 to record 3.9\% and the Suez Canal revenues continued in decreasing to record a negative change rate $-3.6 \%$ during the first half of the financial year 2012/2013 (General Authority for Investment and Free Zones, 2013).

3) The Petroleum sector: FDI inflows in the petroleum sector recorded negative rates which witnessed the escape of investments amounting by $\$$ 710 million during the first half of the financial year 2012/2013 (Ali, 2014).

4) The construction sector: The real estate sector has suffered from weakness during the last 4 years as a result of political unrest and judicial disputes on land obtained by some companies which had subsequently affected the implementation of projects and funding and slowing the sales (General Authority for investment and free zones, 2013).

5) Investment sector: The total implemented investment recorded negative change rate in the financial years (2010/2011) and (2012/2013); in contract it recorded positive change rate in the financial years (2011/2012), (2013/2014) to 2014/2015 during the last 4 years after $25^{\text {th }}$ revolution (Central Bank, the annual report 2010/2011: 2014/2015).

6) Tourism sector: It recorded negative change rate amounted to $-19.5 \%$ during the financial year2010/2011 especially in the second half of the year (CAPMAS, 2015). 
7) Labor force in tourism sector: Labor force in tourism sector was affected by the revolution and the following events, from 2009 to 2011 (Ali, 2014).

8) Tourism investment: The tourism investment in Egypt during the financial year (2006-2007) reached 4.134 million e.g., recording contributory share approximately $2.75 \%$ of the total investments in Egypt. In (2007-2008) the volume of tourism investments reached 5.557 million, recording change rate about $34.42 \%$ compared to the financial year (2006-2007) (Ministry of Finance - monthly financial report 2006/2007 and 2007/2008).

While, in the next financial year 2008-2009 the investment flow in tourism sector reached 5.211 million, achieving a negative change rate nearly $-6.2 \%$ compared to (2007-2008). In the financial year 2009-2010 the change rate in the investment flow in tourism sector estimated by $15.985 \%$, this means, the investment flow in tourism reached 4378 million(Ministry of Finance - monthly financial report 2008/2009 and 2009/2010).

On the other hand, in the financial year (2010-2011) the investment flow in tourism amounted by 5739 million, recording positive change rate roughly by $31.1 \%$. In the next financial year following the revolution (2011-2012) the tourism investment flow reached 5.570 million, recording change rate about $-2.9 \%$ compared to the last financial year (2010-2011) (Ministry of Finance - monthly financial report 2010/2011 and 2011/2012).

The financial year (2012-2013) the investment flow in tourism reached 6630 million e.g., achieving positive change rate about $19.03 \%$. But the investment flow in tourism sector in (2013-2014) decreased to reach 3.432 million e.g., recording negative change rate approximately $-48.2 \%$ in comparison with the last financial year; furthermore, the investment flow in tourism in the financial year (2014-2015) fell down by 2.075 million e.g., recording negative change rate by $-39.5 \%$ compared with the last financial year. In the financial year (2015/2016) achieved an increasing in the volume of tourism investment estimated by 5785 million e.g., recording positive growth rate by $278.79 \%$ (Ministry of Finance monthly financial report 2012/2013, 2013/2014 and 2014/2015).

\section{4- Methodology}

The study uses the quantitative approach to assess the opinions of the key persons of the official tourism authorities in Egypt using a questionnaire. As well as the secondary sources of data such as the official tourism authorities reports and journals, conferences and books that related to the tourism investment. 
It can be shown through this study the current situation of tourism investment in Egypt after the twenty-fifth of January revolution 2011 and its following events, the obstacles facing tourism investment in Egypt and how to overcome them and the most important types of investment which should be focused on increase the tourism incomes in Egypt as it was before twenty-fifth of January 2011.

The sample of the study consists of the key officials at the tourism authorities, number of the human resource directors and some of tourists in hotels in Egypt, in addition; Number of the businessmen and owners of tourism projects. In line with this concern, the questionnaire was developed and directed to:

1- The Egyptian (economic section).

2- Egyptian Tourism Promotion Authority. (ETPA)

3- Egyptian Tourism Federation (ETF)

4- Tourism Development Authority-investment affairs. (TDA)

5- Red Sea Tourism Investment Association Red Sea. (RSTIA)

6- Red Sea Investment Office.

7- Egyptian travel Agencies association. (ETAA)

8- MOT Hurghada branch

9- ETPA Hurghada branch

10- Number of the businessmen and owners of tourism projects in Hurghada and Marsa-alam.

11- Number of the human resource directors and some of tourists in hotels, sample of the hotel that researcher distributed in:

- Palma resort (S.A.E)

- EUROTEL PALM BEACH

- Royal Hotel

- Palm beach resort

- City Star Provage Resort

The questionnaire consists of 16 closed-questions and 7 openedquestions, the closed-questions have five-points Likert scale dividing into four modules, The impact of $25^{\text {th }}$ January revolution 2011 on the tourism investment, Evaluating the tourism investment climate, Investment in human resources and The tourism investment incentives.127 questionnaires were distributed and collected in 25 days during this 
period the respondents completed 97 questionnaires representing a response rate $70 \%$.

After the collection of the questionnaire lists, the researcher has analyzed all data using the statistical package for social science analysis system SPSS version (18).

\section{5-Results and discussion}

After the analysis of opinions and perspectives of the respondents, the Frequencies and Percentages were used to describe the variables and analyze the opinions.

The following tables show the percent and frequencies of the sample opinions for every module.

Table1: The impact of $25^{\text {th }}$ January on tourism investment.

\begin{tabular}{|c|c|c|c|c|c|c|c|c|c|c|c|}
\hline \multirow[t]{2}{*}{$\mathrm{N}$} & \multirow{2}{*}{ Variables } & \multicolumn{2}{|c|}{ Str.agree } & \multicolumn{2}{|c|}{ Agree } & \multicolumn{2}{|c|}{ Neutral } & \multicolumn{2}{|c|}{ Disagree } & \multicolumn{2}{|c|}{$\begin{array}{l}\text { Str.disag } \\
\text { ree }\end{array}$} \\
\hline & & $\begin{array}{l}\text { Fre } \\
\mathrm{q}\end{array}$ & $\%$ & $\begin{array}{l}\text { Fre } \\
\mathrm{q}\end{array}$ & $\%$ & $\begin{array}{l}\text { Fre } \\
q\end{array}$ & $\%$ & $\begin{array}{l}\text { Fre } \\
q\end{array}$ & $\%$ & $\begin{array}{l}\text { Fre } \\
q\end{array}$ & $\%$ \\
\hline 1 & $\begin{array}{l}\text { 1- Twenty-fifth of } \\
\text { January revolution } \\
\text { affected the tourism } \\
\text { investment negatively }\end{array}$ & 53 & $\begin{array}{l}55 . \\
2\end{array}$ & 30 & $\begin{array}{l}31 . \\
2\end{array}$ & 3 & 3.1 & 6 & 6.3 & 4 & 4.2 \\
\hline 2 & $\begin{array}{l}\text { 2- The twenty-fifth of } \\
\text { January revolution } 2011 \\
\text { affected the domestic } \\
\text { and foreign investment } \\
\text { in the same affection. }\end{array}$ & 21 & $\begin{array}{l}21 . \\
9\end{array}$ & 56 & $\begin{array}{l}58 . \\
3\end{array}$ & 5 & 5.2 & 8 & 8.3 & 6 & 6.3 \\
\hline 3 & $\begin{array}{l}\text { 3- Ratio of risk for the } \\
\text { tourism investor as it } \\
\text { was in } 2011 \text { when the } \\
\text { revolution took place }\end{array}$ & 26 & $\begin{array}{l}27 . \\
1\end{array}$ & 36 & $\begin{array}{l}37 . \\
5\end{array}$ & 9 & 9.4 & 15 & $\begin{array}{l}15 . \\
6\end{array}$ & 10 & $\begin{array}{l}10 . \\
4\end{array}$ \\
\hline 4 & $\begin{array}{l}\text { 4- Media and social } \\
\text { media helped in } \\
\text { increasing the negative } \\
\text { impact of } 25^{\text {th January }} \\
\text { revolution on the } \\
\text { tourism investment in } \\
\text { Egypt }\end{array}$ & 28 & $\begin{array}{l}29 . \\
2\end{array}$ & 53 & $\begin{array}{l}55 . \\
2\end{array}$ & 1 & 1 & 9 & 9.4 & 5 & 5.2 \\
\hline
\end{tabular}


Analysis of table (1) shows that:

* $86.4 \%$ of the total sample of the study either agree or strongly agree that "Twenty-fifth of January revolution negatively affected the tourism investment" and only $10.5 \%$ disagree.

* $80.2 \%$ of the total sample of the study either agree or strongly agree that "the twenty-fifth of January revolution 2011 affected the domestic and foreign investment in the same affection" and on the other hand, $14.6 \%$ disagree.

* $64.6 \%$ of the total sample of the study either agree or strongly agree that "Ratio of risk for the tourism investor as it was in 2011 when the revolution took place"; on the other hand $26 \%$ disagree.

* The majority of the respondents amounted by $84.4 \%$ of the total sample of the study either agree or strongly agree that "Media and social media helped in increasing the negative impact of $25^{\text {th }}$ January revolution on the tourism investment in Egypt".

Table 2: Evaluation of the tourism investment in Egypt

\begin{tabular}{|c|c|c|c|c|c|c|c|c|c|c|c|}
\hline \multirow{2}{*}{$\mathrm{N}$} & \multirow{2}{*}{ Variables } & \multicolumn{2}{|c|}{ Str.agree } & \multicolumn{2}{|c|}{ Agree } & \multicolumn{2}{|c|}{ Neutral } & \multicolumn{2}{|c|}{ Disagree } & \multicolumn{2}{|c|}{$\begin{array}{l}\text { Str.disagre } \\
\mathrm{e}\end{array}$} \\
\hline & & $\begin{array}{l}\text { Fre } \\
q\end{array}$ & $\%$ & $\begin{array}{l}\text { Fre } \\
q\end{array}$ & $\%$ & $\begin{array}{l}\text { Fre } \\
q\end{array}$ & $\%$ & $\begin{array}{l}\text { Fre } \\
q\end{array}$ & $\%$ & $\begin{array}{l}\text { Fre } \\
q\end{array}$ & $\%$ \\
\hline 5 & $\begin{array}{l}\text { If you are a businessman, } \\
\text { will you choose Egypt as } \\
\text { a destination for tourism } \\
\text { investment? }\end{array}$ & 5 & 5.2 & 10 & $\begin{array}{l}10 . \\
4\end{array}$ & 10 & $\begin{array}{l}10 . \\
4\end{array}$ & 52 & $\begin{array}{l}54 . \\
2\end{array}$ & 19 & 19.8 \\
\hline 6 & $\begin{array}{l}\text { The risk for the tourism } \\
\text { investor doesn't totally } \\
\text { depend on poor security. }\end{array}$ & 7 & 7.3 & 16 & $\begin{array}{l}16 . \\
7\end{array}$ & 5 & 5.2 & 54 & $\begin{array}{l}56 . \\
2\end{array}$ & 14 & 14.6 \\
\hline 7 & $\begin{array}{l}\text { The promising tourist } \\
\text { areas in Egypt and the } \\
\text { anticipated tourist } \\
\text { situation are encouraging } \\
\text { attracting the foreign } \\
\text { investors and reduce the } \\
\text { risk }\end{array}$ & 5 & 5.2 & 12 & $\begin{array}{l}12 . \\
5\end{array}$ & 11 & $\begin{array}{l}11 . \\
5\end{array}$ & 61 & $\begin{array}{l}63 . \\
5\end{array}$ & 7 & 7.3 \\
\hline 8 & $\begin{array}{l}\text { There is an improvement } \\
\text { in the volume of tourism } \\
\text { investment flow during } \\
\text { the years following } 25 \text { th } \\
\text { January revolution } 2011 \text {. }\end{array}$ & 3 & 3.1 & 27 & $\begin{array}{l}28 . \\
1\end{array}$ & 8 & 8.3 & 46 & 48 & 12 & 12.5 \\
\hline
\end{tabular}


Table 2 reveals that:

(5 $74 \%$ of the total sample of the study either disagree or strongly disagree that "If you are a businessman, will you choose Egypt as a destination for tourism investment"; and only, 15.6\% agree.

$670.8 \%$ of the total sample of the study either disagree or strongly disagree that "The risk for the tourism investor doesn't totally depend on poor security", on the contrary, 24\% agree.

(7) $70.8 \%$ of the total sample of the study either disagree or strongly disagree that "The promising tourist areas in Egypt and the anticipated tourist situation are encouraging attracting the foreign investors and reduce the risk", however, only $17.7 \%$ agree.

$860.5 \%$ of the total sample of the study either disagree or strongly disagree that "There is an improvement in the volume of tourism investment flow during the years following 25th January revolution 2011", whereas, $31.2 \%$ agree.

Table 3: Investment in human resources

\begin{tabular}{|c|c|c|c|c|c|c|c|c|c|c|c|}
\hline \multirow[t]{2}{*}{$\mathrm{N}$} & \multirow[t]{2}{*}{ Variables } & \multicolumn{2}{|c|}{ Str.agree } & \multicolumn{2}{|c|}{ Agree } & \multicolumn{2}{|c|}{ Neutral } & \multicolumn{2}{|c|}{ Disagree } & \multicolumn{2}{|c|}{$\begin{array}{l}\text { Str.disag } \\
\text { ree }\end{array}$} \\
\hline & & $\begin{array}{l}\text { Fre } \\
q\end{array}$ & $\%$ & $\begin{array}{l}\text { Fre } \\
q\end{array}$ & $\%$ & $\begin{array}{l}\text { Fre } \\
q\end{array}$ & $\%$ & $\begin{array}{l}\text { Fre } \\
q\end{array}$ & $\%$ & $\begin{array}{l}\text { Fre } \\
q\end{array}$ & $\%$ \\
\hline 9 & $\begin{array}{l}\text { The drop in the tourism } \\
\text { investment volume affects } \\
\text { human resources } \\
\text { negatively. }\end{array}$ & 21 & $\begin{array}{r}21 . \\
9\end{array}$ & 40 & $\begin{array}{l}41 . \\
7\end{array}$ & 15 & $\begin{array}{l}15 . \\
6\end{array}$ & 18 & $\begin{array}{l}18 . \\
7\end{array}$ & 2 & 2.1 \\
\hline $\begin{array}{l}1 \\
0\end{array}$ & $\begin{array}{l}\text { Training and qualification } \\
\text { of human resources in } \\
\text { advanced and proper way } \\
\text { is from the most important } \\
\text { types of investment } \\
\text { affecting the increase of } \\
\text { tourism income }\end{array}$ & 26 & $\begin{array}{l}27 . \\
1\end{array}$ & 44 & $\begin{array}{l}45 . \\
8\end{array}$ & 6 & 6.3 & 15 & $\begin{array}{l}15 . \\
6\end{array}$ & 5 & 5.2 \\
\hline $\begin{array}{l}1 \\
1\end{array}$ & $\begin{array}{l}\text { Investment in the human } \\
\text { resources is the most } \\
\text { important type of } \\
\text { investment for the } \\
\text { development of any } \\
\text { industry especially the } \\
\text { tourism industry }\end{array}$ & 34 & $\begin{array}{l}35 . \\
4\end{array}$ & 37 & $\begin{array}{l}38 . \\
5\end{array}$ & 6 & 6.3 & 14 & $\begin{array}{l}14 . \\
6\end{array}$ & 5 & 5.2 \\
\hline $\begin{array}{l}1 \\
2\end{array}$ & $\begin{array}{lll}\text { Tourist institutes and } & \text { and } \\
\text { colleges don't play the }\end{array}$ & & & & & & & & & & \\
\hline
\end{tabular}




\begin{tabular}{|l|l|l|l|l|l|l|l|l|l|l|l|}
\hline & $\begin{array}{l}\text { active role to graduate a } \\
\text { qualified human resource } \\
\text { to invest in the tourism } \\
\text { sector }\end{array}$ & 24 & 41 & 42. & 10 & $\begin{array}{l}10 . \\
7\end{array}$ & 18 & $\begin{array}{l}18 . \\
8\end{array}$ & 3 & 3.1 \\
\hline 1 & $\begin{array}{l}\text { the twenty fifth of January } \\
\text { revolution and its } \\
\text { following events } \\
\text { influenced } \\
\text { resources negatively in the } \\
\text { same way that affected the } \\
\text { tourism investment in } \\
\text { Egypt }\end{array}$ \\
\hline
\end{tabular}

Table 3 shows that:

D $63.6 \%$ of the total sample of the study either agree or strongly agree that "The drop in the tourism investment volume affects human resources negatively "; unlikely, $20.8 \%$ disagree.

(2) $72.9 \%$ of the total sample of the study either agree or strongly agree that "Training and qualification of human resources in advanced and proper way is from the most important types of investment affecting the increase of tourism income", and on the other hand only $20.8 \%$ disagree.

3 The majority of the sample estimated by $73.9 \%$ either agree or strongly agree that "Investment in the human resources is the most important type of investment for the development of any industry especially the tourism industry" and in contrast, $19.9 \%$ strongly disagree.

$467.7 \%$ of the total sample of the study either agree or strongly agree that "Tourist institutes and colleges don't play the active role to graduate a qualified human resource to invest in the tourism sector", and only $21.9 \%$ disagree.

5 a great number amounted by $67.9 \%$ of the total sample of the study either agree or strongly agree that "the twenty fifth of January revolution and its following events influenced human resources negatively in the same way that affected the tourism investment in Egypt" and only $19.8 \%$ disagree. 
Table 4: The incentives of tourism investment.

\begin{tabular}{|c|c|c|c|c|c|c|c|c|c|c|c|}
\hline \multirow[t]{2}{*}{$\mathrm{N}$} & \multirow[t]{2}{*}{ Variables } & \multicolumn{2}{|c|}{ Str.agree } & \multicolumn{2}{|c|}{ Agree } & \multicolumn{2}{|c|}{ Neutral } & \multicolumn{2}{|c|}{ Disagree } & \multicolumn{2}{|c|}{$\begin{array}{l}\text { Str.disag } \\
\text { ree }\end{array}$} \\
\hline & & $\begin{array}{l}\text { Fre } \\
q\end{array}$ & $\%$ & $\begin{array}{l}\text { Fre } \\
q\end{array}$ & $\%$ & $\begin{array}{l}\text { Fre } \\
q\end{array}$ & $\%$ & $\begin{array}{l}\text { Fre } \\
q\end{array}$ & $\%$ & $\begin{array}{l}\text { Fre } \\
q\end{array}$ & $\%$ \\
\hline $\begin{array}{l}1 \\
4\end{array}$ & $\begin{array}{l}\text { The state plays an } \\
\text { active role in making } \\
\text { relations with countries } \\
\text { and invites them to } \\
\text { invest in Egypt. }\end{array}$ & 7 & 7.3 & 25 & 26 & 6 & 6.3 & 44 & $\begin{array}{l}45 . \\
8\end{array}$ & 14 & $\begin{array}{l}14 . \\
6\end{array}$ \\
\hline $\begin{array}{l}1 \\
5\end{array}$ & $\begin{array}{l}\text { Tourism investment } \\
\text { incentives provided by } \\
\text { the government are } \\
\text { sufficient to restore } \\
\text { tourism investment } \\
\text { flow. }\end{array}$ & 4 & 4.2 & 19 & $\begin{array}{l}19 . \\
8\end{array}$ & 8 & 8.3 & 50 & $\begin{array}{l}52 . \\
1\end{array}$ & 15 & $\begin{array}{l}15 . \\
6\end{array}$ \\
\hline $\begin{array}{l}1 \\
6\end{array}$ & $\begin{array}{l}\text { There is no relation } \\
\text { between } \\
\text { incentives providing } \\
\text { increasing the tourism } \\
\text { investment volume. }\end{array}$ & 5 & 5.2 & 15 & $\begin{array}{l}15 . \\
6\end{array}$ & 6 & 6.3 & 53 & $\begin{array}{l}55 . \\
2\end{array}$ & 17 & $\begin{array}{l}17 . \\
7\end{array}$ \\
\hline
\end{tabular}

Table 4 shows that:

- $60.4 \%$ of the total sample of the study either disagree or strongly disagree that "The state plays an active role in making relations with countries and invites them to invest in Egypt"; on the other hand, $33.3 \%$ agree.

2 A great number of the total sample of the study amounted by $67.7 \%$ either disagree or strongly disagree that "Tourism investment incentives provided by the government are sufficient to restore tourism investment flow"; while, $24 \%$ agree.

3 The great majority of the sample estimated by $72.9 \%$, either disagree or strongly disagree that "There is no relation between providing incentives and increasing the tourism investment volume"; whereas a little proportion reached $5.2 \%$ agree.

\section{Results of analysis the open-ended questions:}

The respondents identify the most important types of incentives that should be offered to attract tourism investment to Egypt as follows:

* Reducing custom charges and the temporary tax exemption.

* Issuing new laws to facilitate investment and the implementation of the idea of a single window service. 
* Eliminating bureaucracy and centralization.

* Facilitating possessing land for the establishment of investment projects at reasonable prices.

* Spreading Security and stability.

* Raising awareness and improving education and training.

* Canceling fines of delaying authorities' charges and the concerned foundations such as; interests of delaying paying bills of electricity, water, gas, taxes ....etc. imposed on investment projects in Egypt

* Positive role of media.

* Demonstrating the effective role for the private sector to invest in tourism field.

* Improvement of basic services and infrastructure

* Implementation of "the right to benefit" system or "BOT" system.

With regards to the most important types of investment that should be focused on to increase returns of tourism in Egypt, almost all the respondents mentioned:

- Investing in human resources and training and qualifying them with advanced-systems.

- Therapeutic resources development to stimulate an important type of tourism, i.e., "remedial tourism"

- Developing safari tourism and the establishment of environmental hotels and motels.

- Investment in the aviation; by construction new airports with latest technological systems and training the human resources in advanced way to raise their efficiency as well as making effective marketing programs for these projects.

Concerning the efforts that a community must do to promote tourism investment flow in Egypt, the respondents identify:

* Not proceeding with destructive thoughts and corrupt media.

* Upgrading education and improving behavior in dealing with others.

* Studying the manner of generations' evolution.

* Community's awareness that these investment projects will benefit them.

* Preservation of the environment and adhering to the principles and values.

Regarding the role that the government does to attract the tourism investment and promote tourism, almost all the respondents stated:

- Establishing and developing infrastructure in the new and existing areas 
- Spreading security.

- Facilitating measures imposed upon investors' shoulders.

- Opening new doors for investment.

- Youth Rehabilitation and raising awareness.

- Increasing tourism promotion to new destinations that have never been to.

All the respondents agreed that there is a direct relationship between providing incentives and increasing the size of the investment flow. They explained their answer to the competition in the global investment market, especially, surrounding countries, as well as because the investor seeks to achieve the greatest benefits, both fiscal and moral.

Concerning the obstacles that deter tourism investment in Egypt, the respondents determine: Insecurity and political instability, Negative media, Administrative obstacles and the large number of required documents and the length of the proceedings, Bureaucracy and harsh centralization, little awareness and a declined standard of education and Exchange rate instability.

To overcome these obstacles, respondents identify these suggestions:

- Upgrading standard of education and training the human resources.

- Establishing of new tourist areas and developing the existing ones.

- Giving attention to all economic sectors of the state, particularly agriculture, education and establishing new industrial zones to strengthen the Egyptian economy.

Finally, almost all the respondents agreed that the investment in the human element is one of the most important types of investment affecting the growth of tourism income. They explained their answer to the following reasons:

- The human element is the backbone of any field, especially the tourism sector as extremely allergic industry.

- As Egypt has many human resources but unused.

- Taking care of health (by construction new hospitals and provide them with latest medical equipment in addition, making the service accessible to all citizens) and focus on education by developing the curricula and taking care of the teacher as well as the strong control of the educational process; all these lead to increase benefits from these human resources. 


\section{6- Conclusion and recommendations}

\subsection{Conclusion:}

The study dealt with the topic of investment and finance generally in a nutshell; Investment is one of the main pillars of economic development and attracts FDI that helps the development of cities and the interest of all, therefore, investment is defined as that part of GDP, which was not used in the current consumption of a particular year, but was used in adding to the community balance of capital assets to increase the state's ability to produce goods and services in the future. Both investor and host country have motives to achieve their goals, but there are determinants of FDI which represent in market size, growth rate, economic Stability, human resource development, supporting endogenous capacity, providing suitable infrastructure, political stability, regulatory, legislative framework for investment, provides the fabric of local institutions successful and the degree of economic openness to the outside world. In the other hand, the study mentioned the investment decision making as a step in the investment process and that because it may involve a significant risk for the investor, so, there are several phases for investment decision making process and investment management process. After that investment analysis comes to study financial securities for the purpose of successful investing as well as investment income and risk. Finally, investment incentives and new investment law 2015 as well as barriers to investment.

Moreover, Financing considered an integral part of the investment process because it determines the ability of the investor to implement the project, so that the study dealt with some definitions related to finance as definition of finance, financial management, business finance and financial statement and its essential elements. Moreover, the financial risk and financial types which can be broken down into three broad categories; public, private and public/private.

After that, the study mentioned in some detail the tourism investment and its economic importance of tourism investment which can be divided into types of economic analysis related to the tourism sector and used on an international scale. In addition, $25^{\text {th }}$ January revolution 2011, its impact on the important economic sector in Egypt, its impact on tourism and tourism investment in particular.

Finally, the study concluded that:

1- The twenty-fifth of January revolution 2011 and its following events affected the tourism investment and human resources working in tourism sector. 
2- The investment in human resources is the most effective investment type on growing tourist income in Egypt.

3- There is a significant statistics between providing incentives for investment and the increase in these investments flow. (Table 4, question 16) (Analysis of The open-ended questions)

4- Media and social media are the principal factors in increasing the negative impact of the twenty-fifth of January revolution 2011 on tourism investment.

5- There is no risk for the tourism investor "nowadays", related to the impact of $25^{\text {th }}$ January revolution 2011.

\subsection{Recommendations:}

The study sees that it is possible to improve the investment climate and achieve effective cooperation between private investors and political economic decision-makers. In this way, the study suggests a set of recommendations for reviving the tourism investment in Egypt and overcoming obstacles facing tourism investment flow in Egypt. These recommendations are summarized as:

\subsection{1- Recommendations for the state:}

1 - Reducing customs and the temporary tax exemption.

2- Issuing new laws to facilitate investment and the implementation of the idea of a single window service.

3- Eliminating bureaucracy and centralization.

4- Facilitating possessing of lands for the establishment of investment projects at reasonable prices.

5- Spreading Security and stability.

6- Raising awareness and improving education and training.

7- Implementation of "the right to benefit" system or "BOT" system.

8- Focus on training and qualifying human resources in advanced way, on the basis of the investment in human resources is the most important type of investment to increase the tourism income.

9- Developing therapeutic resources to stimulate an important type of tourism, i.e., "remedial tourism" as well as developing safari tourism and the establishment of environmental hotels and motels to open new markets in the Egyptian tourism besides the other existing types of tourism.

10- Investment in the aviation; by construction new airports with latest technological systems and training the human resources in advanced way to raise their efficiency as well as making effective marketing programs for these projects. 
11- Giving attention to all economic sectors of the state, particularly agriculture, education and establishing new industrial zones to strengthen the Egyptian economy.

\subsubsection{Recommendations for community:}

1- Not proceeding destructive thoughts and corrupt media.

2- Improving their behavior in dealing with others.

3- Preservation of the environment and adhering to the principles and values.

\section{References}

1- Abd-Elrahman, S. (2011). "Study of investment climate change impact on incorporation decisions, practical study in Egypt". Master thesis, faculty of economic and political science, Cairo University.

2- Arab investment guarantee, (1993)." the climate investment in Arab countries report-1993". Kuwait, P 59-61.

3- Abd-Elaziz, M. (2005) "FDI in Islamic countries", Dar Elnfaes, Jordon, 2005.

4- Arab Organization for Investment Guarantee Corporation, (1993) "Report of the investment climate in the Arab countries in 1993". Kuwait, p. 59-61.

5- Ali. M, (2014) "The impact of the January 25 revolution on the strategic economic Sectors in Egypt". Available at:

http://www.ahewar.org/debat/show.art.asp?aid=398068 (Accessed on October 2016)

6- Center for International Private Enterprise, (2004) "Foreign Direct Investment", first publishing.

7- Central bank of Egypt annual report 2011:2014 available at:

http://www.cbe.org.eg/public/AnnualRepot.pdf (accessed on October 2016)

8- Central Agency for Public Mobilization and Statistics (CAPMAS) (2012), News, Press Release, 2012, available at: http://capmas.gov.eg/pepo/281.pdf (Accessed on October 2016)

9- Central Bank of Egypt, the annual report 2010-2011: 2014-2015 available online 
http://www.cbe.org.eg/ar/EconomicResearch/Publications/Pages/Ann ualReport.aspx (Accessed on August 2016)

10- Central Agency for Public Mobilization and Statistics (CAPMAS) (2012),News, Press Release, 2012, available at: http://capmas.gov.eg/pepo/281.pdf. (Accessed on October2016)

11-Dwyer, L., Forsyth, P., and Dwyer, W. (2010). "Tourism economics and policy". Channel View Publications. Australia.

12- Endo, K. (2006). "Foreign direct investment in tourism - flows and volumes. In: Tourism Management". 27: 600-614.

13- Fabozzi, F. (1999) "Investment Management". 2nd. edition. Prentice Hall Inc.

14- General Authority for Investment and Free Zones: "an overview of the Egyptian economy in 2013".Cairo: General Authority for Investment and Free Zones, 2013, p. 17.

15- Huda, A. (2008) "The financial globalization impact on FDIAlgeria case study". Master Thesis, Faculty of Economics and Political sciences, University of Haseeba Bin-Ali.

16- Hasab-Alla, A. (2005) "Determinants of foreign direct/indirect investment in Arab economic environment, comparative study (Egypt, south Korea and Turkish)", Al-dar algameyia, Alex, Egypt, 2004, 2005, P 19.

17- Iraqi, M., Abdu-Allah, G. and Latief, H. (2004). "Tourism Development in Egypt, the Economical and Social Impacts on Hurghada Local Citizens". Vol. (1) No, (1), Journal of Association of Arab Universities for Tourism and Hospitality, Faculty of Tourism and Hotel, Suez University.

18- Kikeri, S, Kenyon, T and Palmade, V. (2006)"Reforming the Investment climate, lessons for practitioners". World Bank, Policy Research Working Paper 3986.

19- Meziany, F. (2009) "The domestic committee's role in the investment field". Faculty of law and political sciences, Patnah University, volume 6, pp. 54-66. 
20- Menour, O and Nazir, E. (2000) "The private investment incentives". Economics of North Africa journal, university of Shelf, $\mathrm{N}$ 02, P 117.

21- Meng, Q. (2012). "Corporate investment, financing and payout decisions, Evidence from UK-listed companies". Master's thesis, Birmingham business school, University of Birmingham.

22- Ministry of Planning. "The most important indicators of the economic and social performance during the fourth quarter and the fiscal year 2012/2013". Ministry of Planning, October 2013, p. 7, Cairo.

23- Ministry of Finance - monthly financial report 2006:2015, available online at:

http://www.mof.gov.eg/MOFGallerySource/Arabic/Reportes/2006/12/ allparts.pdf

http://www.mof.gov.eg/MOFGallerySource/Arabic/Reportes/2007/12/ allparts.pdf

http://www.mof.gov.eg/MOFGallerySource/Arabic/Reportes/2008/12/ allparts.pdf

http://www.mof.gov.eg/MOFGallerySource/Arabic/Reportes/2009/12/ allparts.pdf

http://www.mof.gov.eg/MOFGallerySource/Arabic/Reportes/2010/12/ allparts.pdf

http://www.mof.gov.eg/MOFGallerySource/Arabic/Reportes/2011/12/ allparts.pdf

http://www.mof.gov.eg/MOFGallerySource/Arabic/Reportes/2012/12/ allparts.pdf

http://www.mof.gov.eg/MOFGallerySource/Arabic/Reportes/2013/12/ allparts.pdf

http://www.mof.gov.eg/MOFGallerySource/Arabic/Reportes/2014/12/ allparts.pdf(Accessed on December 2015)

http://www.mof.gov.eg/MOFGallerySource/Arabic/Reportes/2015/12/ allparts.pdf(Accessed on March 2016) 
http://www.mof.gov.eg/MOFGallerySource/Arabic/Reportes/2071/1/a llparts.pdf(Accessed on Jun 2017)

24- Myles, D. (2003) "Investment Analysis". University of Exeter, UK.

25- Niskanen, J. and Niskanen, M. 2007"Corporate finance". Edita Publishing, Finland.

26- Ontario Tourism Investment Attraction, research study. Queen's Printer for Ontario, Ministry of tourism, 2009, Canada.

27- Paramasivan, C and Subramanian, T. (without). "Financial Management", New Age International Publisher, New Delhi.

28- Philips, J and Faulkner, J. (2012). "Tourism investment and finance, accessing sustainable funding and social impact capital". Roberta Hilbruner, USAID Donald E. Hawkins, George Washington University.

29- Quiry, P, Dallocchio, M, Le Fur, y and Salvi, A. (2005). "Corporate finance, theory and practice". John Wiley \& Sons Ltd, The Atrium, Southern Gate, Chichester, West Sussex, England.

30- Tianen, P. (2013). "Driving factors of tourism investment decisions and Lapland's attractiveness in tourism investments". Master's degree thesis, Laura University of applied sciences.

31- UNCTAD, (2010). "Promoting foreign investment in tourism", United Nation publication, New York and Geneva.

32- Wagdi, Kh. (2009). "Tourism investment and its impact on the tourism development, comparative study between Egypt and Spain". master thesis, faculty of economic and political science, Cairo.

33- World Bank, World Development Indicators, available on line at:http://databank.worldbank.org/data/views/variableSelection/select variables.aspx?source=worl d-development-indicators (accessed on October 2016) 